\title{
SPRING AND SUMMER PREY OF BURROWING OWLS IN ALBERTA
}

JOSEF K. SCHMUTZ, Department of Biology, University of Saskatchewan, Saskatoon, Saskatchewan. S7N OW0, and GWENDOLYN and DANIEL WOOD, Box 74, Castor, Alberta. TOC 0X0

When animals show a preference for one type of habitat over another, there are at least two different features of the habitat that could be the cause: food, and suitable cover which affords protection from predation. In attempts to conserve natural populations, it is useful to understand which factor is important and at what time of year. Declines in the distribution of Burrowing Owls in western Canada have been primarily attributed to loss of grassland habitat. Other factors, including a shortage of nest burrows, the use of insecticides and rodent poisons, and the shooting of owls, are considered secondary. ${ }^{18}$

We examined pellets, prey remains and feeding habits of Burrowing Owls in the Hanna area of southeastern Alberta in spring and summer. We suspected that cricetine rodents (mouse/vole) may be an important food source after the owls arrive in spring, while insects may be more easily obtained and, therefore, ${ }_{6}$ predominate in the owl's summer diet. ${ }^{6}$

\section{Study Area and Methods}

The owls nested in a semi-circular band encompassing the towns of Dorothy, Sunnynook, and Richdale, south and east of Hanna, Alberta. The brown soils exist in a "swell and swale topography" with approximately $15 \%$ of the land under cultivation for dry-land agriculture. Past annual precipitation was approximately $40 \mathrm{~cm}$ per year. ${ }^{5}$
We found owl nests by inquiring from landowners, by searching previously used nesting areas, and during an ongoing study of prairie raptors in the region. ${ }^{11}$ We examined 234 pellets collected from 11 nests at nine different times (418 days apart) between 30 April and 4 July 1990. We collected whole pellets and those which had fallen apart but were still identifiable as one pellet. Our main aim was to identify prey items to class (Insecta, Aves, Mammalia) but we also identified items to genus and species where possible. For identification we compared the prey remains to specimens collected in the field, to insect collections held at the University of Saskatchewan, and to field guides. ${ }^{1,16}$ When we found insect and rodent parts in one pellet we assumed that the owl, not the rodent, had eaten the insect. In addition to recording the prey classes represented in each pellet, we attempted to quantify prey items by counting the minimum number of individuals represented in a pellet, using elytra, wings, jaws, or pelvic girdles for counting individuals. ${ }^{10}$ Because a rodent skull could have been included in one pellet and most of the fur of the same rodent in another pellet, we quantified conservatively by counting mice only by skeletal remains.

\section{Results}

Prey: In a total of 234 pellets we found rodent bones of fur in 202, insect parts in 136, a lower jaw of a juvenile Richardson's Ground Squirrel in one, 
and feathers in two pellets. Our conservative count suggests that the owls consumed $136(35 \%)$ cricetine rodents, 247 $(64 \%)$ insects, $2(<1 \%)$ birds and 1 $(<1 \%)$ juvenile Richardson's Ground Squirrel.

Although rodents were apparently an important prey item in all four months, the owls took more rodents in April-May than in June-July (Fig. 1). The proportion of pellets that contained rodent, insect or rodent and insect parts combined varied over time $(\mathrm{G}=21.21, \mathrm{df}=6, \mathrm{P}<0.001)$.

Since we could never actually examine the owls' nests, we rarely found parts or whole prey. During the five years of our Burrowing Owl study, we recorded only ten whole prey items. These included three voles (Microtus sp.), three mice (Peromyscus sp.), one
Richardson's Ground Squirrel, one Tiger Salamander, and two frogs (Rana or Hyla sp.).

Some prey fragments in the pellets allowed us to identify prey items beyond the class or family level. Examining 98 lower jaws we found that the owls preyed on 1.45 vole for every mouse. Identifiable arthropod parts included those of grasshoppers (Acrididoidea), and beetles (Nicrophorus sp. and Melanoplus sp.). The large number of carrion beetles (Nicrophorus sp.) in comparison with the rarity with which we observed them in the field was striking.

Foraging Habits: In comparison to the much larger rodent prey, insects probably require more energy expended by the

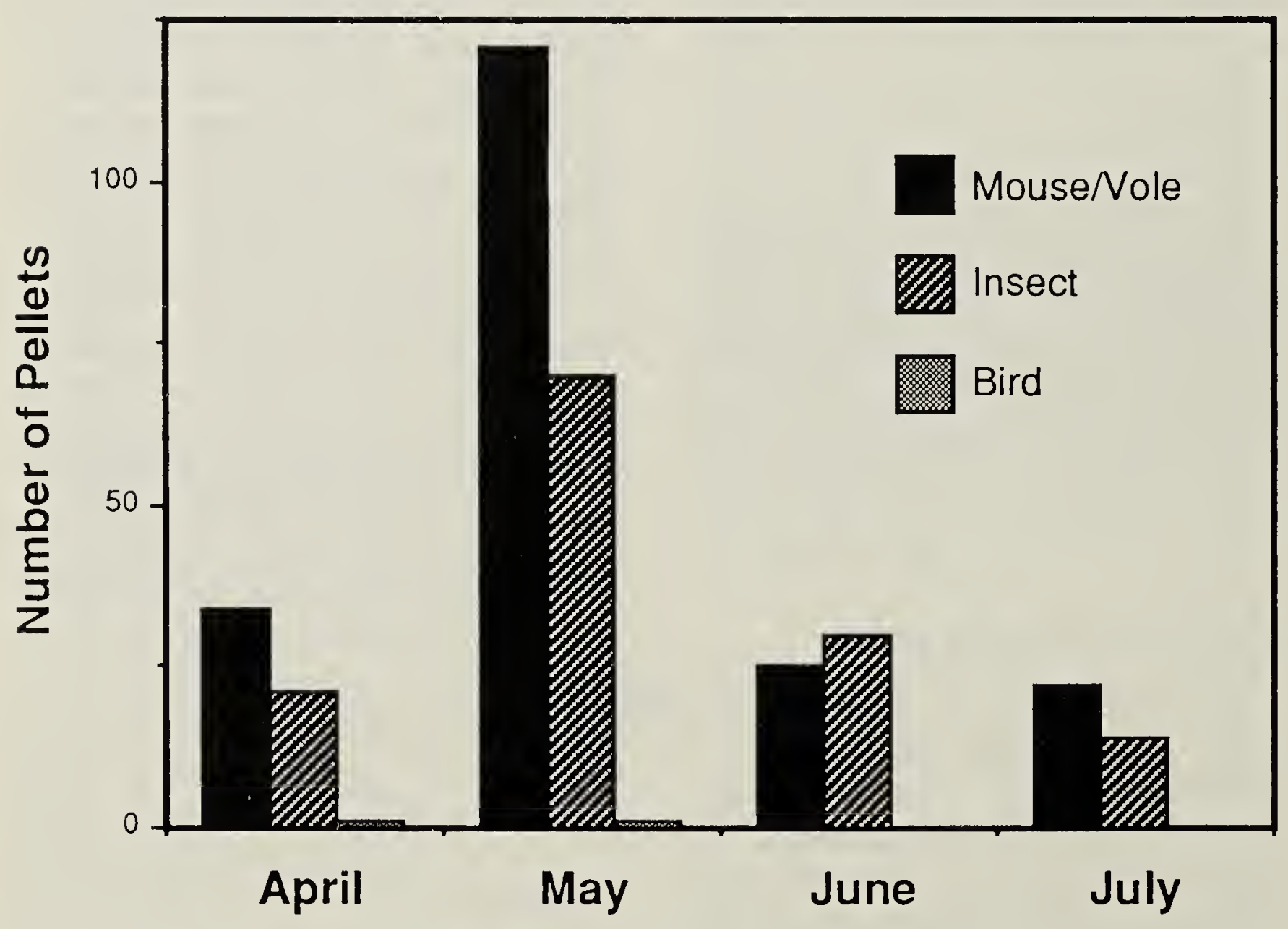

Figure 1. The number of Burrowing Owl pellets containing the remains of mouse/vole rodents, insects, and birds in southeastern Alberta in 1990. The actual number of pellets is inflated because we included pellets with insect and mouse/vole remains combined in both the insect and mouse/vole categories. 
hunting owls per unit energy gained. We recorded feeding habits of owls in detail at 19 nests. Of the five hunting methods employed by Burrowing Owls as described by Haug, we have noticed four in the field. ${ }^{5}$ Owls roosting on burrow mounds frequently ran a few metres to capture insects: "ground hunting." According to our observations, this was the first hunting style employed by fledgling owls. One owl flew approximately 20 times in ten minutes from the mound into the air at a steep angle, caught insects and returned to the burrow mound: "flycatching." We saw owls intently looking around from a perch, "perch hunting," and "hovering," but never "gleaning" insects from tall vegetation.

Whether insects were taken in mid-air or on the ground, they were always caught with the talons. When "flycatching," the owl focused on the flying insect, flew in a straight line, swerved up to capture the insect, turned immediately and retumed to the original vantage point on the ground. In most cases the insect was transferred to the beak during the glide back to the ground. Such flights were usually $10-30 \mathrm{~m}$ long and never longer than $75 \mathrm{~m}$. The owls rarely missed their prey on calm days, but did so more frequently on windy days. After each miss, the owl returned to the mound and did not pursue the insect. Rodents, in contrast, were pursued vigorously when missed.

The net energy gain by owls employing "ground hunting" may be greater than those using flight. Insects were usually spotted by the owl a short distance away and caught in a pounce. In one instance, when an owl flew $500 \mathrm{~m}$ from the nest which we visited, the owl took approximately $30 \mathrm{~min}$. to return, walking leisurely within $30 \mathrm{~m}$ of the nest, pouncing on many insects along the way.

We assigned sex to the owls based on plumage coloration (D. Wood unpubl. data). We observed both males and females feeding their young on the mound. However, when the young were underground the male transferred the prey to the female who disappeared below ground. We have never seen a male enter the nest burrow when young were present. According to Bent, Borrowing Owls have "stockpiled" prey in the nest burrow. ${ }^{2}$ At a nest outside the study area, we have observed a stockpile of over 50 grasshoppers with legs that have been removed and piled nearby. When eating rodents, the owls reject viscera at least some of the time. ${ }^{12}$

\section{Discussion}

Studies of food habits of hole-nesting owls are biased in favour of prey with sizeable keratinized or ossified parts because counts of prey items rarely can be used in these species to correct for bias inherent in the pellet analysis. ${ }^{10,14}$ Our study is subject to this bias also. Nonetheless, we believe that our results suggest convincingly that mouse/vole and insect prey are important to Burrowing Owls. Some of the less common prey items may have gone undetected. The results of our study are in general agreement with other studies that suggest that cricetine rodents, arthropods, and birds form the main food of Burrowing Owls. ${ }^{5,15,17}$

The owls in our study took more voles than mice as prey. Conversely, our trap sample included more mice that voles. During 7500 trap-nights, set to include the cool evenings and mornings, we caught 113 mice and six voles. ${ }^{11} \mathrm{Be}$ cause we did not leave our traps set for the entire day, we may have underestimated the abundance of the diurnal voles in relation to the noctumal mice.

Haug studied the food habits of Burrowing Owls on a study area south of Saskatoon, Saskatchewan, approximately $400 \mathrm{~km}$ ENE of our area. ${ }^{6}$ Some differences in the owls' food habits were 
apparent between the two areas. On the Saskatoon study area, where land use involved extensive cultivation, small mammals were apparently much less important in the owls' diet (5\% of identifiable items) compared to our study (35\%). Grasshoppers were more important as prey on the Saskatoon study area (95\% of items) than near Hanna (64\%). Based on Agriculture Canada and Alberta Agriculture survey data, our study area was in a region of low to moderate grasshopper density compared to other areas of Alberta - from $0-2 / \mathrm{m}^{2}$ to $4-6 / \mathrm{m}^{2}$ between 1982 and $1986 .{ }^{9}$

Carrion beetles appeared to us to be more common in the owls' diet than in the field. It is conceivable that the beetles were attracted to the prey stored in the owls' burrows and thus fell prey to owls. Smith and Murphy also found a high number of carrion beetles in Burrowing Owl pellets. ${ }^{15}$ They suggested that the owls, which in their study apparently fed on roadkilled Black-tailed Jack Rabbits (Lepus californicus), may have found carrion beetles at the rabbit carcasses.

Owls in our study tended to have higher average brood sizes (range 4.25.7 between 1986 and 1989) ${ }^{13}$ than other populations in Manitoba and Saskatchewan. ${ }^{6}$ This comparatively high productivity may be linked to the protection of the grassland resource and the ranching economy which predominates in our study region. During our study, only approximately $15 \%$ of the grassland was cultivated. Grassland has been protected by the Special Areas Board of the municipal government, since the 1920 s. $^{4}$ The protection of grassland, through a restriction on cultivation and grazing pressure, may have encouraged populations of voles and mice. Overgrazing of grassland is detrimental to cricetine rodents, the owls' prey. ${ }^{3}$ A source of cricetine rodent prey may have been particularly important to the owls in spring when insects are inactive on cold days and energy demand is high during egg laying. This hypothetical scenario suggests that the conservation of Burrowing Owls not only requires the protection of grassland, but also the maintenance of grassland in a state where vegetation can support a viable cricetine rodent community. It is noteworthy that while populations of this species are still declining in Saskatchewan (P. James, pers. comm.), our study population appears to be stable.

The owls' habit of not consuming the viscera of rodents may be instrumental in reducing a potential detriment that could arise from rodent poisoning campaigns. ${ }^{11}$ James et al. could find no difference in adult owl survival or reproduction between control areas where ground squirrels were poisoned by strychnine. ${ }^{8}$ Similarly, Swainson's Hawks, which also reject the viscera of their ground squirrel prey, survived after eating poisoned ground squirrels with viscera removed. ${ }^{11}$

\section{Acknowledgements}

We acknowledge Carrie, Cody, Ray-Anne and Richard Mashon for collecting pellets for us. David Moody painstakingly teased the pellets apart and recorded prey. We also thank Dylan and Norah Moody for collecting pellets and noting prey found. Local landowners were graciously hospitable to us, especially Greg and Karen Gordon. We are grateful to Bob Randell for identifying arthropod remains. Betsy Haug provided helpful comments on an earlier version of this manuscript. This project was supported by the Endangered Species Recovery Fund (Co-sponsored by Environment Canada, Canadian National Sportsmen's Shows, and World Wildlife Fund Canada), the Alberta Fish and Wildlife Division, the Alberta Recreation Parks and Wildlife Foundation, the Special Areas Board of Hanna, and the University of Saskatchewan.

1. BANFIELD, A.W.F. 1974. The mammals of Canada. University of Toronto Press, Toronto.

2. BENT, A.C. 1961. Life histories of North American birds of prey. Part 2. Dover Publications, Inc., New York. 
3. BOCK, C.E., J.H. BOCK, W.R. KENNY, and V.M. HAWTHORNE. 1984. Responses of birds, rodents and vegetation to livestock exclosure in a semidesert grassland site. J. Range Manage. 37:229-242.

4. GORMAN, J. 1988. A land reclaimed the story of Alberta's Special Areas. Gorman and Gorman Ltd., Hanna, AB.

5. HARDY, W.G. 1975. Alberta - A natural history. M.G. Hurtig Publ., Edmonton.

6. HAUG, E.A. 1990. National recovery plan for the Burrowing Owl. Prepared for the World Wildlife Fund Canada, Toronto.

7. HAUG, E.A. 1985. Observations on the breeding ecology of Burrowing Owls in Saskatchewan. M.Sc. thesis, University of Saskatchewan, Saskatoon.

8. JAMES, P.C., G.A. FOX, T.J. ETHIER. 1990. Is the operational use of strychnine to control ground squirrels detrimental to Burrowing Owls? J. Raptor Res. 24:120-123.

9. JOHNSON, D.L. and A. WOROBEC. 1988. Spatial and temporal computer analysis of insects and weather: grasshoppers and rainfall. Mem. Ent. Soc. Can. 146:33-48.

10.MARTI, C.D. 1979. Raptor food habits studies. Pages 67-79 in B.A. Giron Pendleton, B.A. Milsap, K.W. Cline and D.M. Bird, [eds.], Raptor Management Techniques Manual. National Wildlife Federation, Washington, D.C.

11.SCHMUTZ, J.K. and D.J. HUNGLE. 1989. Populations of Ferruginous and Swainson's hawks increase in synchrony with ground squirrels. Can J. Zool. 67:2596-2601.

12.SCHMUTZ, J.K., K.A. ROSE, and R.G. JOHNSON. 1989. Hazards to raptors from strychnine poisoned ground squirrels. $J$. Raptor Res. 23:147-151.

13.SCHMUTZ, J.K., G. WOOD, and D. WOOD. 1989. Conservation biology of Burrowing Owls: survival, habitat use and differences between populations. Unpubl. Rept. University of Saskatchewan, Saskatoon, SK.

14. SIMMONS, R.E., D.M. AVERY, and G. AVERY. 1990. Biases in diets determined from pellets and remains: correction factors for a mammal-bird eating raptor. $J$. Raptor Res. 25: (in press).

15.SMITH, D.G. and J.R. MURPHY. 1973. Late summer food habits of adult Burrowing Owls in central Utah. J. Raptor Res. 7:112-115.

16. STEBBINS, R.C. 1966. A field guide to western reptiles and amphibians. Houghton Mifflin Co., Boston.

17. THOMSEN, L. 1971. Behaviour and ecology of Burrowing Owls on the Oakland Municipal Airport. Condor 73:177-192.

18. WEDGWOOD, J.A. 1978. The status of Burrowing Owls in Canada. Prepared for the Committee on the Status of Endangered Wildlife in Canada, Canadian Wildlife Service, Ottawa.

The wind is an ardent woman.

She sees in sand the still image of her lover, water.

She combs his hair into long waves.

F. Lehrman. 1988. The Sacred Landscape. Celestial Arts, Berkeley, CA. 